This item was submitted to Loughborough's Research Repository by the author.

Items in Figshare are protected by copyright, with all rights reserved, unless otherwise indicated.

Information in the national liberation struggle: modelling the case of Namibia (1966-1990)

PLEASE CITE THE PUBLISHED VERSION

PUBLISHER

(c) Emerald

LICENCE

CC BY-NC-ND 4.0

REPOSITORY RECORD

Sturges, R. Paul, Mbenae Katjihingua, and Kingo J. Mchombu. 2019. "Information in the National Liberation Struggle: Modelling the Case of Namibia (1966-1990)”. figshare. https://hdl.handle.net/2134/558. 


\title{
INFORMATION IN THE NATIONAL LIBERATION STRUGGLE: MODELLING THE CASE OF NAMIBIA (1966-1990)
}

Paul Sturges (Loughborough University), Mbenae Katjihingua and Kingo Mchombu (both University of Namibia)

Published in Journal of Documentation, 61(6) 2005.

KEYWORDS Information warfare, Intelligence, Propaganda, Suppression of Information.

\begin{abstract}
The Namibian liberation struggle, 1966-1990, is discussed as an information war, rather than a military conflict, so as to explore the dimensions of information activity under conditions of conflict. This builds upon the idea, expressed by participants in earlier struggles of this kind, that the contest for 'hearts and minds' is more significant than the armed confrontation that accompanies it. A model that incorporates information and communication activity by both contestants, at their command centres, in the field and in the media was elaborated in a previous paper, using data from a number of conflicts mainly in Southern and Central Africa. The present paper focuses on the Namibian struggle so as to examine the capacity of the model to assist in explaining the outcomes of the conflict. Using published sources, printed archive material and oral testimony, the range of information inputs, the incidence of suppression of information and information outputs are set out in the pattern provided by the model. This shows how both sides used covert intelligence gathering, secret communication, propaganda and disinformation, accompanied by censorship and the suppression of critical comment by force to further their political/military aims. Whilst South Africa and its Namibian military structures were generally successful in armed confrontation with the chief liberation organisation (SWAPO)'s forces, they were not able to bring the conflict to a successful military conclusion. This was because SWAPO's attention to the diplomatic war, based on strong and consistent information flows, convinced the United Nations and other allies to press for a negotiated solution. Once this was agreed, the success of the liberation movement's news and education campaigns in attaching the people to the cause of liberation was revealed by SWAPO's overwhelming success in free elections in 1989.
\end{abstract}

\section{INTRODUCTION}

The liberation struggles that brought independence to a large number of African and Asian colonies and dependencies during the second half of the twentieth century are still comparatively little studied by historians, given their significance in setting the pattern of modern international politics. The idea that they might offer scope for the historian of information and communication activities is certainly one that seems not to have occurred until recently. There is a hint in Toffler and Toffler (1993).

Discussing the concept of information warfare they draw attention to asymmetrical conflicts that oppose industrialised states or multinational corporations with peasant economies or small, poorly funded ideologically driven organisations. Rayward 
(1996) is slightly more explicit, suggesting that the colonial wars of independence might prove interesting to historians from an information-centred viewpoint. In pursuit of such hints, a model of information in the liberation struggle has already been set out in a previous paper and illustrated with content from a number of struggles, mainly in Southern and Eastern Africa (Sturges, 2004). The present paper turns this approach to Namibia, and begins to make use of the model rather than just describing and elaborating it. In what follows it is intended to demonstrate how information can be treated as the main focus of the liberation struggle in Namibia. The model provides a strong structure for a case that information activity was the source of the eventual outcome of the struggle.

Published literature, printed archive material and newly collected personal testimony provide content for the model. A programme of interviews, individual and group, was carried out between September 2002 and June 2003 with the aid of a grant from the Emerald Literati Research Fund. Whilst this was a small programme of data gathering and no substitute for a major, systematic research exercise, it did nevertheless enrich and sometimes redirect the desk-based research. Namhila (2000) notes that relevant interview material that has been collected by various individuals and projects in Namibia has not been brought together as a single substantial resource. Researchers are thus obliged to carry out new fieldwork, and although this might sound like a waste of effort it has the enormous virtue of taking them away from the desk and out to the locations and participants in events. The interviews with political activists, former exiles and media professionals used here, are presented anonymously (identified at the first mention with a letter of the alphabet and the interviewee's occupation and subsequently by letter only). Some interviewees requested this anonymity, so it has been extended to all.

\section{THE MODEL}

The guiding spirit of the model is the formulation by Bernard Fall of the revolutionary war as:

$$
\text { RW (revolutionary war) = G (guerrilla warfare) }+ \text { P (political action }) \text {. }
$$

In this formula, Fall (1967) points out that 'The kill aspect, the military aspect, definitely always remained the minor aspect: the political administrative, ideological aspect is the primary aspect.' The validity of this is amply evident from a critical reading of the evidence provided in surveys and discussions of the subject from Heilbrunn (1962), Taber (1970), Van der Haydte (1972), through to Joes (1996), Lacquer (1998), Beckett (2001) and others. It is the case, even though recognition of the paramountcy of the non-violent aspects of the struggle may not be explicit in an author's commentary. Schell (2003, p.97) is quite explicit on this, calling it 'the eclipse of the power that flowed from superior military might by the political power that flowed from the hearts and minds of the people'.

What applies to those conducting revolutionary struggle applies equally to those countering it on behalf of the established regime. The model systematises the crucial non-military aspects of the struggle, all of which have a predominant information and communication orientation, in a way that is intended to: 
1. Structure knowledge of different types of information and communication activity:

2. Indicate gaps and concentrations in activity;

3. Permit audit and assessment;

4. Assist in an understanding of outcomes;

5. Provide perspectives on information warfare in other contexts.

In the previous article, the first three of these were tested with a variety of examples drawn from the literature. The information-related discussion of the struggle in Namibia (1966-90) that follows is the beginning of an exploration of the capacity of the model to perform the fourth of these aims. The fifth is largely left for the reader to judge: the focus here is on the Namibian liberation struggle as such.

The distinctive thing about the model is that it gives equal expression to both the liberation movement's information and communication activities and the equivalent activities of the established power's counter-insurgence programme. It is genuinely a model of conflict: not just a formal model that merely accommodates interference from political and military conflict. It first divides information and communication elements, on both sides, into three spheres of information activity: the field, the headquarters and the media. It then further divides information activities into three types according to whether they are concerned with information input (acquisition and processing of information); information output (the dissemination of messages); and information suppression. Each of these divisions by aspect is further divided into its overt and covert elements. Thus input includes both the overt, information acquisition and research, and the covert, espionage and surveillance. Output includes both the overt preparation and distribution of formal propaganda and political education messages, and the covert passing on of operational messages. Suppression covers both the overt censorship of documentation and speech, and the covert control of critical and hostile thought through the 'suppression' of individuals and their ideas.

The model enables types of activity to be set in the context of the spheres of activity. This places overt input and output types of activity within the headquarters sphere; covert input and suppression activities in the field sphere; and overt and covert output and suppression activities into the media sphere. The way the model expresses this can be shown in graphic fashion as a circle divided into three with the three divisions further subdivided, thus: 


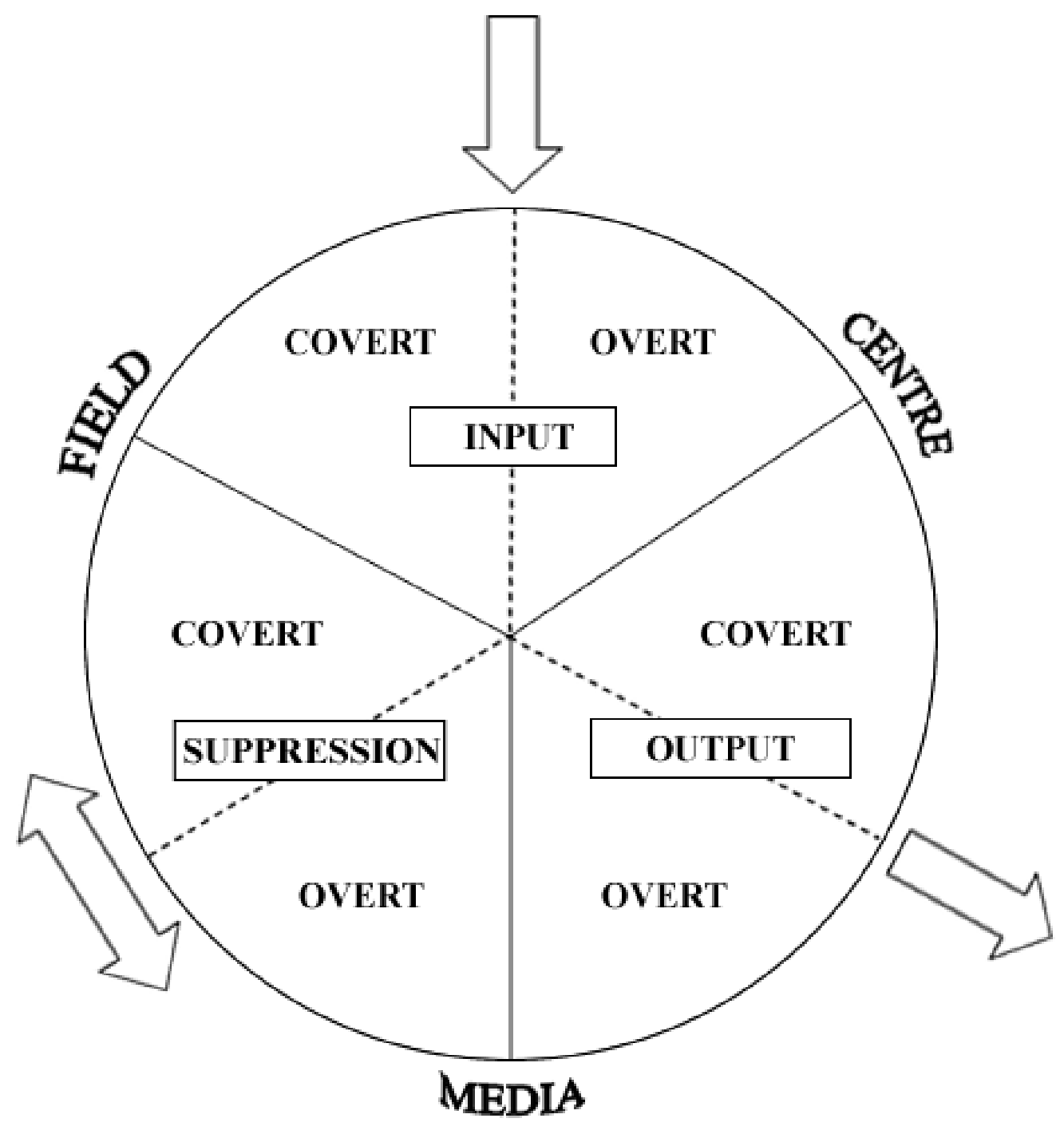

The Model 
This diagram has, however, to be duplicated to accommodate two different sets of data, one concerning the activities of the liberation movement, and the other concerning those of the established regime. The two circles then contain sets of data about the same types of activity in shared spheres. These two different versions of the model then need to be placed in relation to each other. This can be done in the form of a striking metaphor. The two circular geometrical planes can be seen as resembling the faces of two millstones. If one of the planes is rotated through 180 degrees to face the other, the two can be imagined grinding against each other in an opposition resembling the attritional aspects of warfare. The power imparted through the centre of both stones in a mill from some energy source such as wind or water to create movement, could then be imagined as the purposive use of information by both contestants in what constitutes a very distinctive form of information management. In an unpublished conference presentation of the model in 2001, it was illustrated by a moving image rather than the static diagram that is all that can be offered here.

\section{NAMIBIA}

Namibia is a country of over $800,000 \mathrm{sq} \mathrm{kms}$ in the southwest part of Africa, mainly bordered by South Africa, Botswana and Angola. Although thinly populated (not much over 1.8 million people) it has rich mineral resources, plentiful sea fisheries along its coast and considerable agricultural and tourist potential. Much of the country is desert and dry land, with about half of the population concentrated in Ovamboland, along the northern, Angolan border, and about $10 \%$ in the capital, Windhoek, in the centre. The country has a number of language and ethnic groups with differing traditions, though English was adopted as the national language at the time of independence.

In 1884 the German Empire annexed the territory, with all its diverse ethnic groupings, as South West Africa. There was considerable resistance to colonial rule by Namibia's various peoples, including the San, culminating in a tragic war, 190407, in which the Herero and Nama peoples and their allies were defeated and subjected to a campaign of genocide. During the First World War South Africa successfully invaded the colony and in 1921 it was constituted a League of Nations trust territory, administered by South Africa. In 1947 South Africa attempted to annex the country, but the League's successor, the United Nations, refused to agree. Abandoning this approach in 1961, South Africa then sought to establish South West Africa as a quasi-independent client state. During the whole period South Africa integrated many aspects of the country into the apartheid system, with Africans allowed only about $10 \%$ of the land and confined to townships in the capital and other towns. The more densely populated north was used as a labour reserve for the farms and factories of the white-owned preponderance of the land. The modern phase of resistance was spiritually rooted in the earlier armed conflicts but took form in the labour organisations led by the Ovamboland People's Congress, and involving many of the future leaders of the South West African People's Organisation (SWAPO). In 1966 SWAPO took up armed resistance and in 1968 the United Nations agree to declare South African occupation illegal. 
Until 1975 SWAPO's efforts were frustrated by a lack of suitable bases outside Namibia's borders, but Angolan independence in that year changed this completely. From Angola a more intensive military campaign could be launched in 1982 and 1983, mainly in the Ovambo north. This was suppressed by massive military deployment, but at the same time South Africa failed in diplomatic initiatives designed to produce a settlement that would preserve its effective control of the country. A five point plan suggested by an international Contact Group was unacceptable to both sides and a puppet democratic government of the territory proved so critical of South African policy that it was removed. From 1983 onwards a colonial administration was in place and South Africa fought a military campaign within Angola to remove SWAPO's cross border bases. This campaign exhausted both Angola and South Africa and when in 1988 a Cuban/Angolan army completely halted South African military incursion at Cuito Cuanevale, negotiations for independence became the chief focus of the struggle. Internationally supervised elections in 1989 brought a massive SWAPO majority and independence was made formal in March 1990.

\section{NAMIBIA 1966-1990 AS AN INFORMATION WAR}

This outline clearly indicates that SWAPO's victory was not a conventional military triumph. Of course this was also true to an extent of many successful anti-colonial struggles, in which exhausted and disillusioned regimes handed over power to militarily inferior opponents that, nevertheless, could not be eradicated. In the other cases (mainly Malaysia, Kenya and Zimbabwe) discussed in the paper already mentioned that developed the model, it could be argued that military and information campaigns were counterbalanced aspects of a single struggle. What will be suggested here is that a closer examination of the struggle in Namibia shows that the information conflict was by far the most dominant and significant contributor to the eventual outcome. By setting aside the conventional rhetoric of conflict and discounting the journalistic and historical concentration on the events of war, the categories available in the model enable us to perceive the pattern of underlying policy emphases that actually resolved the conflict. The way we will approach this is to concentrate first on input aspects, both at the command centres and in the field. We will then turn to suppression, an element present in this model in a way that does not feature strongly in conventional information models. Finally we will look at output, which will be the area in which we would expect the lessons regarding the outcome of the struggle to become most apparent.

\section{Input -information management and espionage}

Information input, in the formal sense, was naturally a sector in which South Africa, as an economy and polity with highly developed sectors, was well equipped to excel. At the headquarters of the government ministries and agencies in Pretoria and Windhoek there was the capacity to acquire, process and interpret information gathered from sources worldwide. Information activities were pervasive. The Bureau of State Security (BOSS) managed an extensive network of espionage and surveillance activity, which included the activities of a range of police, military, and paramilitary agencies within both South Africa and Namibia. The effectiveness of South African intelligence in disrupting the communications of the liberation 
movement was always a threat (Interviewee K, Clergyman). To support this activity, South African military command had powerful communications facilities at its disposal. For example, 'A sophisticated microwave radio-telecommunications system, imported from the British firm Marconi, connects the northern war zone with military nerve centres in Walvis Bay and South Africa' (SWAPO, 1981, p.106). More conventional forms of information input included the Statistical Office in Windhoek, an offshoot of the South African Statistical Office in Pretoria, which was capable of collecting and systematising data from the day-to-day processes of government in Namibia itself. To take advantage of this wealth of information input, high ranking political committees served by expert staff and consultants were marshalled for intelligence, planning and command purposes throughout the struggle.

In contrast, the liberation movement as represented by SWAPO, began the struggle with virtually no headquarters information capacity and had to build systems and facilities with limited financial and personnel resources. That it did this highly successfully was clearly because it was identified as a key policy aim and because it proved possible to convince the United Nations of the significance of this aim. The chief expression of SWAPO's success in developing appropriate capacity was the United Nations Institute for Namibia (UNIN). The purposes of the Institute, established in Lusaka, Zambia, in 1976, included developing administrative personnel for the future independent country. Interviewee $\mathrm{C}$, a local government officer, trained at UNIN and gained administrative experience in the refugee camps. He was instructed in public speaking, debating, report writing, correspondence and other management skills and identifies the training as something that has subsequently been of benefit to many current Namibian politicians and administrators.

UNIN was also a centre for the training of researchers and it provided an information and documentation centre of vital significance (SWAPO, 1981, p.297). Reviewing its effect, Asombang and Singini (1990, p.79) suggest that:

The Institute's research output has impelled South Africa and its surrogates in Namibia to publish hitherto unavailable information on Namibia albeit with the intention, inter alia, of defending the South African position or further misrepresenting and distorting the facts.

United Nations assistance was crucial, but there was other relevant help from governments (Finland and the German Democratic Republic for example), international religious bodies and support groups in various parts of the world. This included building information capacity through provision of education and training for Namibia exiles and help with textbook development for the educational programmes in the refugee camps.

Headquarters information activity is of course dependent on the volume and quality of the information inflow, as are operational activities in the field of conflict. Here the contrast tends to be between the systematic intelligence gathering of the established power and the intimate daily connection of the freedom fighters with the population. Leys and Saul (1995) set out the way in which SWAPO meetings were penetrated by spies whenever possible, a network of informers was established, mail was opened, phones tapped and a whole apparatus of state surveillance was continuously built up. A notorious example was the trial of two men accused of the murder of Chief Elifas (a government supporter) in 1975 (Katjavivi 1988, p.82). The defence lawyers felt that the prosecution showed awareness of their intentions and discovered that the woman 
operating the court switchboard and telex machine was passing on documents. A successful appeal against a guilty verdict to a still reasonably independent judiciary was based on this interference.

South Africa also turned similar techniques against its own forces. Feinstein (1998, p.95) reports that phone calls home were not respected - 'the military censors frequently eavesdropped, betraying their presence with coughs, grunts and giggles'. In the military conflict, chiefly in the north of Namibia, the South Africans could call on sophisticated equipment and specialised units, which are outlined by O'Brien (2001) and described in anecdotal detail by Stiff (1999). South African regular and conscript units had also to rely on field intelligence gathered with the assistance of local support units of the South West Africa Territorial Force (SWATF) and Koevoet special forces. The personnel of both of these originated in bodyguard troops, the omakakunya or scavengers, recruited by traditional leaders. Patrols were accompanied by San trackers, the so-called 'buddies' of whom Feinstein (1998, p.38) said:

It was soon apparent that when on patrol we were totally reliant on them for information and directions. Such was our dependence we would never have made it back to camp in the evenings without their guidance.

Effective though the South African intelligence gathering may have been it never enabled the regime to root out the SWAPO local presence completely or make military activities safe within Namibia’s borders.

SWAPO's intelligence gathering capacity was of necessity totally clandestine. In the early years of the conflict PLAN (People's Liberation Army of Namibia) guerrillas moved comparatively easily about the northern region. The movement's policy stressed political education as the initial activity of the guerrillas when they entered the country from exile. The other side of this was to make it possible that 'the people were also their eyes and ears, providing them with essential military intelligence' (SWAPO, 1981, p.178). After 1982 and the intensification of the South African military campaign 'the politicising role of the guerrillas who moved continuously and easily among the people of Ovamboland, often in civilian clothes, able to communicate and convince, began to wane' (Leys and Saul, 1995, p.32). However, SWAPO as an organisation was not actually banned by the government, though for the most part treated in practice as if it were. The survival of an organisational structure within the country meant that a certain capacity for communication remained. Interviewee A, a SWAPO official, described the levels of concealment that this called for, with body language sometimes as important as messages in words.

During these later years of the struggle, a range of organisations, such as trades unions, women's groups, and student representative bodies carried on the activity within Namibia. Interviewee $\mathrm{H}$, a company director, spread the message through work with societies, residents' associations, high school students and a range of other organisations. Interviewee I, a senior civil servant, was an organiser with the SWAPO Youth League and would carry on the work whilst ostensibly coaching football and netball clubs. The role of the church, particularly the Lutherans, Anglicans and Catholics, was central to this. Interviewee $\mathrm{K}$ described some sermons as more like political speeches than preaching, and was himself politicised by this social gospel. The churches not only denounced South African policy, but also provided a structure for peaceful resistance and: 
Through regular worship services, catechetical and confirmation groups, Sunday schools, newspapers and other informative publications, choirs, youth groups, women's organisations, pastoral work, travel and cross-cultural contacts, the churches constitute a pervasive network for communication about vital issues. (Ellis, 1984, p.52)

These networks of clandestine activity meant that even when rendered militarily ineffective within Namibia's borders SWAPO could receive the intelligence that was vital to the successful pursuit of its aims. On the other hand, it led to the suggestion, exploited as much as possible by the regime, that the external forces of SWAPO did not represent opinion within the country. Furthermore, it was maintained that there was a split between internal and external SWAPO. Although energetically denied by Nujoma and the leadership, it seems clear that external SWAPO was, at the least, in danger of detachment from internal opinion. Only when elections became possible could the strength of this be tested.

\section{Suppression - censorship and the silencing of comment}

The distinctive feature of information in the liberation struggle is that it is suppressed as enthusiastically as it is sought and made available. To detail the complexity and unrelenting attention to detail of the South African censorship in its Namibia is way beyond the capacity of this paper. Merritt (1994) gives a full history of the South African laws and regulations and their administration. Most, but not quite all, of this legislative apparatus was also in force in Namibia. An International Labour Office mission to Namibia in 1977 drew attention to the Publications and Entertainments Act of 1963. 'This controls publications, films and public entertainments through a Board, which may prohibit the printing or producing of any undesirable publication or object; as well as its display or dissemination'. (International Labour Office, 1977, p.78) The mission noted that by 1975 about 25,000 items had been banned. Other legislation that could be used to reinforce this included a Newspaper Imprint and Registration Act, which required new newspapers to pay a nominal deposit.

When the Namibian newspaper was founded in 1985 to campaign for independence and the freedom of information, an attempt was made to levy a damaging 20,000 rand deposit under this law. The failure of the law to suppress the Namibian was extremely significant, not merely in terms of the publication's internal impact. 'The paper's photographs - vivid images of the conflicts, contradictions and chaos of Namibian life - appeared in books, journals, and on gallery walls and TV screens throughout the world'. (Lush, 1989, p.93) For the whole course of the conflict the regime kept comment and information in Namibia under a heavy censorship, also using the Publications Act of 1975 and aspects of the Defence Act, Police Act, Prisons Act and Internal Security Act for censorship purposes. Under emergency regulations of 1986 periodicals were forbidden to leave blank space on their pages to represent censored material (Namibia Ministry of Information and Broadcasting, 1991). At the same time, messages supporting the liberation case were never wholly absent from the press in Namibia. A serious alternative press, much of it provided by religious organisations, always managed to survive and tell the story ( Heuva, 2001). Interviewee $\mathrm{J}$, a senior academic administrator, credited these publications with feeding his own political consciousness. 
The liberation movement, as essentially clandestine in its own country and a guest in the friendly countries that harboured it, had no comparable formal powers. What it did exercise was a certain ability to suppress opposing comment through its own organisational processes. Two major crises in SWAPO's conduct of the campaign were suppressed by internal procedures. The first in 1976 centred on Andreas Shipanga who was, to some extent coincidentally, the SWAPO Secretary for Information and Publicity. Shipanga was at the centre of what the SWAPO leadership characterised as a South African inspired attempt to overthrow the leadership. Others have seen it as an attempt to be more responsive than the current leadership to the concerns of the flood of Namibian refugees who left the country after 1975. Some South African military successes at this time were seen to suggest that the dissident members had passed information to them. This was used as powerful argument for the suppression of Shipanga and his immediate associates, who were expelled from the party and its Zambian headquarters. Certainly their viewpoint was effectively silenced by these procedures. A second 'spy' scandal in 1984 was dealt with through the detention of an admitted one hundred suspects, though higher figures were sometimes alleged. South African propagandists exploited this episode as a basis for attacks on SWAPO (Herbstein, 1987) and it is used as such in publications such as Hooper (1988)'s journalistic account of time spent with Koevoet. SWAPO leader Sam Nujoma nevertheless maintained the detention was a valid counter to South African spying campaigns (Nujoma, 2001, p.356).

What is definitely the case is that on both sides of the conflict the formal suppression of hostile comment and damaging information was accompanied by covert activity that involved the silencing of real and supposed enemies by detainment, torture and killing. The South African security forces harassed and threatened independent journalists, such as those of the Namibian, and the army attempted to discourage a major advertiser by removing its business from the company. The paper also suffered bomb attacks, a tactic that was used to devastating effect against another source of anti-government comment in May 1973 when the printing press of the OvamboKavango Church was expertly blown up. Attacks on critics, suspected political activists and innocent people seen as potential sources of military or political intelligence were too numerous to sum up here, but that these were instruments of policy is clear. Cliffe (1994, p.24) reports an estimate that of all those killed in the Namibian conflict, Koevoet, the spearhead of South African covert operations, murdered $80 \%$ of them.

SWAPO policy documents stress political education and peaceful change more than they emphasise the need for armed struggle. 'SWAPO perceived the armed struggle as a continuation of the political struggle through violent means' (Mbuende, 1986, p.155). However, there is also ample evidence to show that cruel suppression was used when it seemed to be required (Groth, 1995). Whilst this cannot be excused in moral terms, it is certainly explained by the pressures of covert warfare. Amongst its other effects of the constant threat to individual safety, whether from friend or foe, was the development of a culture of concealment of thoughts and an avoidance of documentary recording. As Moorsom (1990, p.89) put it. 'There is another side to confidentiality. Control of recorded information is vital to Namibians organising clandestinely and to the liberation movement itself. Here lives are constantly at stake.' The paucity of written records of everyday experience of the conflict is in itself 
evidence of the bitterness of the covert struggle for the hearts and minds of Namibia's people.

\section{Output - propaganda, education and communication}

The attempts at suppression outlined above did not prevent powerful flows of information and effective communication. South African propaganda efforts were extremely well funded, thorough and, to a certain extent, effective. White South African and Namibian opinion and a significant section of (mainly right wing) opinion worldwide were kept attached to the South African cause. The South African Department of Information coordinated activities and had secret budgets and accounts in other ministries and offices in at least 18 other countries (African National Congress, 1985). These activities were complex and far-reaching, stretching into agencies and companies such as the South African Tourist Corporation and South African Airways and using high profile advertising agencies such as Saatchi and Saatchi. External propaganda came to be seen as so important that it was placed directly under the Ministry of Foreign Affairs. The SWA/Namibia Information Service received funds for overseas activity and had offices in the USA, Britain, Germany and France (König, 1988). These created a flow of press stories and radio and TV contributions. A range of magazines and newsletters such as Namibia in Focus and Namibia News appeared from the London-based Namibia Information Service and were distributed to politicians, schools and libraries. Potentially friendly politicians and other influential figures were invited to visit Namibia, both in the hope of confirming their support, and of using their presence for propaganda effect.

The comparative success of these campaigns was not matched in terms of communication to those actually experiencing the struggle within Namibia. South Africa relied heavily on radio for internal propaganda. As a South African government minister put it 'The radio is the only way to get through to the Bantu and reach his soul' (African National Congress, 1985, p.1). The regime chose FM for its broadcasting because of the quality of reception, but more significantly because its reach was comparatively limited. If people could be encouraged to use FM receivers they would be unable to listen to short wave broadcasting from distant stations. The SWA Broadcasting Corporation and Radio Ovambo, sarcastically known as Radio Puppet, interspersed deliberately attractive FM music transmissions with political messages. Whilst listeners enjoyed the music they switched off the news and disregarded the political messages. People thought to be liars might be told 'You're talking FM' (Mosia et al, 1994). The message could be so crude that even a serving South African soldier listening to a Communications Operations officer felt that 'His speech immediately convinced me that if he was being serious, the war was irretrievably lost' (Feinstein, 1998, p.16). Official broadcasting to the white population actually avoided the political issues as much as possible, keeping content light and unchallenging (Interviewee F, broadcaster). What is more, Interviewee B a broadcaster with experience working for both sides made it clear that those working for the SWABC African languages services subtly subverted the official messages by their choice of words.

It was a great strength of SWAPO that it also fully appreciated the need for a double propaganda front: internal and external. Whilst it was possible, the liberation fighters of PLAN pursued an education-based programme. 'Political instructors lecture the 
cadres with the aid of books and pamphlets produced by SWAPO, as well as those from countries in support of our struggle' (SWAPO, 1981, p.262). Then they had the responsibility to 'return these ideas and information to the masses in an articulate form and pose new questions with a view to deepening the political understanding of the masses' (SWAPO, 1976, p.9). Shipanga (1973, p.16), before his expulsion from office with SWAPO, described the work of small, secret groups 'The cells distribute propaganda among the population. They gather information about the enemy's movements'. Interviewee $\mathrm{C}$ and Interviewee $\mathrm{G}$, a provincial politician, both attributed some of their own politicisation to this type of political education activity. On the other hand other interviewees did not mention it all and, like Interviewee E a librarian, mentioned other sources of inspiration such as political songs and poems.

Clearly a great deal of the most significant activity took places in the schools. Schooling was a communication base on which the regime relied. As Ellis (1984, p.49) put it, 'Radio has been second only to the schools in the consciousnessmoulding operations of the South African government'. SWAPO's education policy (SWAPO, 1984, p.6) described the Bantu Education System as the 'extreme but logical outcome of colonialism'. It was delivered in mother tongue only and, ironically, it was poorly funded, with teachers who were often untrained (International Labour Office, 1977, pp.41-46). If the content of this system failed to convince, the whole foundation of apartheid rule in Namibia was undermined. This was, indeed, precisely the case. A focus group of members of SWANU (alongside SWAPO, the other most significant political movement in pre-independence Namibia) talked of the intense political environment in the schools and the ineffectiveness of formal teaching and textbooks in countering this. Indeed teachers might well speak out against the system and Interviewee $\mathrm{J}$ recalled a particularly inspiring lesson in which a brave teacher graphically set out the historical roots of oppression. Students in the Bantu Education system very frequently protested with strikes and exam boycotts, and leaflets against the system were distributed throughout the country's schools.

After 1975 when it became possible to cross the borders, tens of thousands of highly politicised young people left Namibia and their education became a major enterprise for SWAPO. In Angola the schools were first at Kassinga and then after the bloody South African raid in May 1978, at Kwanza Sul. By the early 80s there were an estimated 8-10,000 learners in Kwanza Sul and 2000-2500 in Zambia (Ellis, 1984). New teachers were trained, textbooks were produced, and because the education was in English, successful students could apply for and obtain scholarships for further study in a number of friendly countries in Africa, Europe and elsewhere. There was a vision that 'The whole of Namibia should be turned into a huge classroom' (SWAPO, 1984, p.18). Former students of the SWAPO education system, such as Interviewee E and Interviewee $\mathrm{D}$, an academic administrator, testify to its quality and the way it provided a basis for the further study that became the base for their professional careers in independent Namibia.

SWAPO's educational investment was complemented by a propaganda effort within Namibia. Even the SWANU focus group cited SWAPO pamphlets as a source of information and political messages. Early activists testify to the influence of print in their politicisation. John Ya Otto on being given a political leaflet claimed that 'The crumpled sheet felt like fire in my hands; we'd be in trouble if someone caught us with this' (Ya Otto, 1982, p.29). Interviewees $\mathrm{E}$ and $\mathrm{H}$ also mentioned this feeling that 
print was dangerous and exciting. However, interviewees cited a great variety of reading that influenced them. Interviewee $J$ read copies of Ghana Today with its messages about how an independent African state might function and thrive.

Interviewee $\mathrm{K}$ came from a family in which the teachings of Marcus Garvey, the Jamaican forerunner of black power, were a great influence, Interviewee $\mathrm{H}$ had access to books and periodicals from South Africa, and Interviewee I read Julius Nyerere's essays on African socialism whilst at secondary school. The influence of print was considerable, even if it was not always it was not material specific to the Namibian struggle that had the greatest impact.

A much more obviously influential activity of the SWAPO Department of Information and Publicity was Voice of Namibia radio. This was preceded from 1966 by brief daily broadcasts from Tanzania, and Voice of Namibia as such was broadcast first from Zambia in 1973 and then from Luanda in 1976. Voice of Namibia sought to provide a diet of political messages and news, encouraging people to support the PLAN combatants. Although it required short wave receivers, research by the South African Human Sciences Research Council in 1978 showed good levels of penetration (Mosia et al, 1994). The success of Voice of Namibia led to official attempts to jam its broadcasts, but these were expensive and annoying to listeners who found they also interfered with reception of other stations. Interviewee B, who had initially worked for SWABC, became a Voice of Namibia broadcaster after going into exile. His evidence shows the professionalism of the station's broadcasters and their ability to assemble convincing Namibian news from monitored South African broadcasts, newspaper stories, information from travellers and freshly arrived exiles and United Nations documentation. Its listeners inside Namibia were numerous and one interviewee after another cited it as a valued source of information.

An effective external propaganda effort was a vital complement to the campaign to inform Namibians inside the country. Having obtained the moral advantage provided by the United Nations' rejection of South African rule, the SWAPO leadership was tireless in building upon it (Moleah, 1983). 'Our missions in many countries, our constant presence at international conferences, and the annual meetings of the OAU, the Movement of Non-Aligned Countries and the UN General Assembly, increased worldwide support to our cause' (Nujoma, 2001, p.198). South African intelligence fully grasped the significance of this. Interviewee $J$ cites an attempted break in at his London home, when he was working for SWAPO in Europe, as a clear indication that the regime was desperate to disrupt this activity. Publications reinforced the message, and titles included the official journal Namibia Today, Action on Namibia and Namibian News Briefing. In 1987 a news agency, NAMPA, was launched, and there was also the Namibia Communications Centre in London, which relayed news obtained from church sources in Namibia to the rest of the world. The effort to ensure that the freedom movement as far as possible held the high moral ground in world opinion was a success, it eventually made SWAPO possibly the best funded liberation movement ever, and when the struggle shifted to the diplomatic arena gave SWAPO a winning advantage.

This emphasis on the overt propaganda efforts of both sides should not be allowed to obscure the clandestine side that existed alongside. South Africa was justly regarded as the world leader in black propaganda, misinformation and disinformation. These skills were used extensively in Namibia. Whilst the distribution of leaflets and other 
printed material by the liberation movement in Namibia was necessarily clandestine, South Africa countered it in ingenious ways (SWAPO, 1978). In 1976 anti-SWAPO comic books were printed in various local languages with a cover showing an armed man gunning down a priest. Earlier, pamphlets were distributed with a cover depicting Nujoma and SWAPO Secretary for Information and Publicity Daniel Tjongarero with lions' heads eating little children. Whispering campaigns were started, alleging that SWAPO intended to kill all old people. In 1977 copies of the SWAPO publication Ombuze ya Namibia, then still on sale, were forged with misleading content. But SWAPO was able to claim that 'Every move by the occupation regime has been exposed by the nation-wide distribution of leaflets and by meetings to inform the people and discuss tactics' (SWAPO, 1981, p.251).

Yet it is important to remember that political opinion in Namibia cannot be looked on as if it were like a blank canvas on which politicians could paint the picture of their choice. This was true for the liberation movement almost as much as it was for the regime. Perhaps the most striking aspect of the interview evidence is the way it reasserts the power of older modes of communication and ideas rooted in the folk memory. Interviewee J talked of stories with historical and political content told by the village elders around the fire and interviewee $\mathrm{K}$ said that the elders talked of politics almost every day. Family was also cited by the SWANU focus group as a source of political ideas and influence and this was echoed by a number of interviewees. SWAPO propaganda had to convince a public whose views that had been worked out in a multiplicity of independent ways. The independence elections of 1989 were the test of whether it was true or not that SWAPO had won the clandestine information struggle.

\section{CONCLUSIONS}

Once South Africa recognised in 1989 that its military effort in Angola had failed and that the consequence would be renewed SWAPO ability to send its members through the long and indefensible northern border as fighters and propagandists, the only answer was a negotiated settlement. Because it was clear that 'SWAPO's exile leadership came to articulate the voice of Namibia that was most clearly heard in international fora' (Leys and Saul, 1995, p.40) their aims in the negotiations were broadly achieved. SWAPO's conduct of its struggle had followed a classic course: 'A strategy that both unites opposition within the territory against the regime, and that achieves a degree of international acceptability is pursued to achieve a sense of national legitimacy' (Burns, 1994, p.52). This had not been an accident. In Sam Nujoma (2001)'s autobiography he makes it absolutely clear that SWAPO strategy had three prongs: mass mobilisation, diplomatic activity and the armed struggle. However, the armed struggle was hardly a success. It has been called 'possibly the most inept in the Third World' (Dobell, 1998, p.20), and Burns (1994, p.30) claims that SWAPO achieved power 'without ever establishing any meaningful military presence in the country, let alone following the textbook of guerrilla war in the form of establishing liberated zones'. The best interpretation of this is that it is the textbook of guerrilla war that needs to be revisited rather than SWAPO strategy.

At the same time as SWAPO's military effort was arguably achieving little, the diplomatic effort was a triumph. The international opinion and, in particular, the UN 
Resolutions that South Africa had felt able to ignore for so many years assumed their full significance in 1989. Forced to accept UN Resolution 435, South Africa was then committed to holding a national election in Namibia in which SWAPO could be a full participant. This effectively threw both parties in the struggle back almost entirely on their ability to persuade. At this point SWAPO's success in mass mobilisation was put to the test. South Africa did not switch its tactics in this new situation. 'State radio and television continued to pour out anti-SWAPO vitriol as if the fighting had never ceased' (Herbstein and Evenson, 1989, p.179). There was also the problem for SWAPO of the doubts that were cast on its fitness to govern by exposure of its treatment of the alleged spies detained in the mid 80s. The movement was obliged to express contrition for much of this, and in the end the propaganda attacks it sustained proved fruitless. In November 1989 SWAPO won a conclusive victory in the polls. This victory was achieved despite the limitations that the struggle had placed on the exile leadership's ability to communicate on an open basis with the SWAPO organisation in Namibia. As Herbstein and Evenson (1989, p.178) put it, the people 'did not all support SWAPO, but they despised South Africa and held the empty shell of the interim government in contempt'. Then, 'The better international organisation of SWAPO thus combined with the visible sources of legitimacy to assist legitimisation of their position as leaders of the opposition and natural heirs to power over their claimed territories’ (Burns, 1994, p.59).

It is important to remember that this was not just a struggle between rival information systems: in the end it was about the content those systems carried. Throughout the struggle the chief problem faced by South Africa was not the capacity to handle and exploit information, but the policy framework within which information was handled. Apartheid and the apartheid mentality were both the reason for the acquisition and management of information and the reason why the quality of output was so frequently flawed. 'Regardless of this attention to [military] detail, it is clear that the failure of the South African actions was due to the inability to offer an acceptable political alternative' (O’Brien, 2001, p.105) South Africa was able to wage enormous military campaigns, but fatally hampered in the conduct of an information war.

SWAPO, despite all its inherent disadvantages - exiled, matched with a powerful and resourceful opponent, required to survive and compete almost solely by persuasion succeeded. The purpose of this paper is not to devalue the suffering and tragic loss of life that occurred throughout the Namibian struggle. Nevertheless it is important to establish that the war was much more a clash of information related activities directed at hearts and minds than it was of guns and bombs. When this is demonstrated, as in the foregoing pages, we can perhaps learn from the fact that the contestant most effectively committed to waging war by peaceful means was victorious.

\section{BIBLIOGRAPHY}

African National Congress (1985) Apartheid propaganda offensive: an integral part of the strategy for survival. Unpublished paper submitted to the Commonwealth Secretariat, $13^{\text {th }}$ May 1905. National Archives of Namibia.

Asombang, W. and Singini, R. (1990) Methodological and statistical issues in research in Namibia. In: Duggal, N.K. ed. Namibian bibliography and documentation. Lusaka: UNIN. pp.79-84. 
Beckett, I.F.W. (2001) Modern insurgencies and counter-insurgencies: guerrillas and their opponents since 1750. London: Routledge.

Burns, D. (1994) Insurgency as a struggle for legitimation: the case of Southern Africa. Small Wars and Insurgencies 5(1) 29-62.

Cliffe, L. (1994) The transition to independence in Namibia. Boulder, Col: Lynne Reiner.

Dobell, L. (1998) Swapo’s struggle for Namibia 1960-1991: war by other means. Basel: P. Schlettwein Publishing.

Ellis, J. (1984) Education, repression and liberation in Namibia. London: Catholic Institute for International Relations, World University Service.

Fall, B. (1967) Last reflections on a war. New York: Doubleday.

Feinstein, A. (1998) In conflict. Windhoek: New Namibia Books.

Groth, S. (1995) Namibia: the wall of silence. Wuppertal: Peter Hammer Verlag.

Heilbrunn, O. (1962) Partisan warfare. London: George Allen and Unwin.

Herbstein, D. (1987) The propaganda war. Africa Report 32(5) 35-38.

Herbstein, D. and Evenson, J. (1989) The devils are among us: the war for Namibia. London: Zed Books.

Hooper, J. (1988) Koevoet! Johannesburg: Southern Book Publishers.

Hueva, W. (2001) Media and resistance politics: the alternative press in Namibia, 1960-1990. Basel: P. Schlettwein Publishing.

International Labour Office (1977) Labour and discrimination in Namibia. Geneva: ILO.

Joes, A.J. (1996) Guerrilla warfare: a historical, biographical and bibliographical sourcebook. Westport, Conn: Greenwood.

Katjavivi, P. (1988) A history of resistance in Namibia. London: James Currey.

König, B. (1988) South Africa's propaganda efforts in Britain. In: Wood, B. ed. Namibia 1884-1984: readings in Namibia's history and society. London: Namibia Support Committee. 727-732.

Lacquer, W, (1998) Guerrilla warfare: a historical and critical study. $2^{\text {nd }}$ ed. New Brunswick, NJ: Transaction Publishers. 
Leys, C. and Saul, J.S. (1995) Namibia’s liberation struggle: the two edged sword. London: James Currey.

Lush, D. (1989) The role of the media in the struggle for liberation: the case of Namibia. Development Dialogue 2 88-98.

Mbuende, K. (1986) Namibia, the broken shield: anatomy of imperialism and revolution. Malmo: Liber Förlag.

Merrett, C. (1994) A culture of censorship: secrecy and intellectual repression in South Africa. Cape Town: David Philip.

Moleah, A.T. (1983) Namibia: the struggle for liberation. Wilmington, Del: Disa.

Moorsom, R. (1990) Data for research on Namibia: a Western scholar's experience. In: Duggal, N.K. ed. Namibian bibliography and documentation. Lusaka: UNIN. pp.85-97.

Mosia, L., Riddle, C. and Zaffiro, J. (1994) From revolutionary to regime radio: three decades of nationalist broadcasting in Southern Africa. African Media Review 8(1) 124.

Namhila, E. (2000) Archives in Namibia. In: Preservation of a Namibian heritage: the establishment of a Documentation and Research Centre on the history of anti-colonial resistance and the liberation struggle of the Namibian people. Windhoek, 15-16 March 2000. Windhoek: Ministry of Basic Education and GTZ. pp.1-9.

Namibia Ministry of Information and Broadcasting (1991) Namibia's information policy. Windhoek: Ministry of Information and Broadcasting.

Nujoma, S. (2001) Where others wavered: the autobiography of Sam Nujoma. London: Panaf.

O’Brien, K. (2001) Special forces for counter-revolutionary warfare: the South African case. Small Wars and Insurgencies 12(2) 79-109.

Rayward, B. (1996) Introduction [Special issue on History of Information Science] Information Processing and Management, 32 (1) 1-2.

Schell, J. (2003) The unconquerable world: power, non-violence and the will of the people. London: Allen Lane.

Shipanga, A. (1973) Interviews in depth: Namibia, SWAPO 1. Richmond BC, Canada: LSM Information Center.

Stiff, P. (1999) The silent war: South African recce operations 1969-1994. Alberton, SA: Galago.

Sturges, P. (2004) Information in the national liberation struggle: developing a model. Journal of Documentation, 60(4) 428-448. 
SWAPO (1976) Political programme of the South West Africa People's Organisation of Namibia. Lusaka: SWAPO Department for Publicity and Information.

SWAPO (1978) Information in the people's resistance. Lusaka: SWAPO Department of Information and Publicity.

SWAPO (1981) To be born a nation: the liberation struggle in Namibia. London: Zed Press.

SWAPO (1984) Education for all: national integrated education system for emergent Namibia. A handbook of the Educational Programme of SWAPO of Namibia.

Luanda: SWAPO Department of Education and Culture.

Taber, R. (1970) The war of the flea: a study of guerrilla warfare theory and practice. St. Albans: Paladin.

Toffler, A. and Toffler, H. (1993) War and anti-war: survival at the dawn of the $21^{\text {st }}$ century. Boston: Little, Brown and Co.

Van der Haydte, F.A. (1972) Modern irregular warfare. Translated edition 1986. New York: New Benjamin Franklin House.

Ya Otto, J. (1982) Battlefront Namibia. London: Heinemann. 